\title{
Model and strategies for the development of coffee in Jambi Province to respond the global market demand
}

\author{
Rosmeli \\ Development Economics Department, Faculty of Economics and Business, \\ Universitas Jambi, Indonesia \\ Correspondence author email:zeadevina@gmail.com ${ }^{\mathrm{a}}$
}

\begin{abstract}
Indonesia is one of the world's top coffee producing countries after Brazil, Vietnam, and Colombia. Although not as the largest coffee producers, Jambi Province has three types of coffee as the region's mainstay product, namely Robusta coffee, Arabica coffee, and Libtukom (Liberika Tungkal Komposit) coffee. The demand for these three types of coffee is quite high. However, there are various problems faced including low land productivity, crop failure, and distribution channels that are not profitable for farmers. Based on this, the study aims to formulate a model and strategies for developing Jambi Province's coffee. Main data used were derived from coffee farmers, experts and stakeholders, and related agencies. Data were analyzed using SWOT and QSPM analysis. It was found that there are eight priority strategies for developing Jambi Province's coffee, namely 1) cutting off distribution channels, 2) working directly with relevant agencies, 3) increasing promotion of Jambi's coffee, 4) coffee as one of the Jambi Province icons, 5) coffee product innovations, 6) cooperation with export destinations, 7) improving knowledge and processing technology, and 8) improving human resources.
\end{abstract}

Keywords: Coffee, Farmer, QSPM, SWOT

JEL Classification: Q13, Q17, Q18

\section{INTRODUCTION}

Coffee is an agricultural commodity that has an important role in the Indonesian economy. According to Indonesian Coffee Exporters Association (Asosiasi Eksportir Kopi Indonesia/AEKI) (2017), Indonesia is one of the world's largest coffee producing countries after Brazil, Vietnam, and Colombia. Based on the type of coffee that most widely cultivated in Indonesia, Robusta occupied the largest proportion (81.96\%), while Arabica was only cultivated $18.04 \%$ of the total area of coffee plantations in Indonesia (Martauli, 2018). Even so, more than $90 \%$ of the total plantations are cultivated by smallscale growers who own about 1-2 hectares of land. This has an impact on difficulties to safeguard stable production volumes and quality; hence its competitiveness in international market is less strong (Indonesia Investment, 2018).

In 2017, the value of Indonesia's coffee exports reached 469.4 million US dollars (ICO, 2017). Most of Indonesia's coffee production is exported to foreign countries and the rest is marketed domestically. Indonesia exported coffee to five continents, namely Asia, Africa, Australia, America, and Europe. Its main market share is in Europe. Large coffee production in Indonesia is the main capital for the coffee industry development, especially for Arabica and Robusta coffee. International market is a potential market for this industry in addition to the domestic market. Indonesian coffee has a different taste, 
so that it has high economic value and is favored by foreign coffee lovers (Sudjarmoko, 2013). Increasing the economic value of coffee can also be done by diversifying the coffee products. According to Kustiari (2016), coffee product diversification could be done at MSME which provides benefits for farmers.

Jambi Province is one of the coffee producing provinces in Indonesia. Robusta, Arabica, and Libtukom (Liberika Tungkal Komposit) Coffee are produced there and become the regions' mainstay. These three types of coffee are planted each in different regions. Robusta is concentrated in Merangin Regency, while Arabica is in Kerinci Regency, and Libtukom Coffee is planted in West Tanjung Jabung Regency. Jambi Province's coffee plantations cover a total area of 26,666 Ha, consisting of 22,521 Ha of Robusta plantations, 1,535 Ha of Arabica plantations, and 2,610 Ha of Libtukom. Coffee production in Jambi Province in 2017 was 14,323 tons, with coffee production of 2,043 $\mathrm{kg}$ per hectare. The number of coffee farmers in Jambi Province is 20,814 farmers (Estate Crops Office of Jambi Province, 2019).

Coffees from Jambi are highly favored in foreign countries such as Malaysia, Singapore, Belgium, and Netherlands. It is thanks to the distinctive taste that differentiates it with coffee beans from other regions. However, the high demand is not followed by the increase in coffee production. There are unresolved problems such as crop failure and distribution channels that do not benefit farmers despite various attempts to increase the production by farmers. Therefore, it is necessary to have a model and strategies for the development of coffee commodity in Jambi Province.

\section{METHODS}

The study was conducted in three regencies in Jambi Province, namely Merangin Regency, Kerinci Regency, and West Tanjung Jabung Regency. The three regencies are coffee plantation centers in Jambi Province. Specifically, Merangin Regency is the center for Robusta, Kerinci Regency is for Arabica, and West Tanjung Jabung is for Libtukom.

Primary data and secondary data were used and obtained from farmers and stakeholders/key informant. Sampling in coffee farmers used Cluster Sampling method. The distribution of the number of samples based on regency is given in Table 1.

Table 1. Sample distribution by regency

\begin{tabular}{rlrc}
\hline No & Regency & $\begin{array}{c}\text { Number of coffee } \\
\text { farmers }\end{array}$ & Samples \\
\hline 1 & Merangin (Robusta) & 9.327 & 45 \\
2 & Kerinci (Arabica) & 9.150 & 44 \\
3 & West Tanjung Jabung (Libutkom) & 2.337 & 11 \\
\hline & Total & 20.814 & 100 \\
\hline
\end{tabular}

Survey results on farmers are the basis for formulating strength, weakness, opportunity, and threat in the coffee commodity development of Jambi Province. To formulate a model and development strategy for coffee, a SWOT analysis is done. The analysis is based on data derived from interviews with four stakeholders/key informants: 1) Estate Crops Office of Jambi Province, 2) Trade and Industry Service of Jambi Province, 3) Regional Development Planning Agency of Jambi Province, and 4) Lecturers from Jambi University].

SWOT (Strength, Weakness, Opportunity, Threat) is one of the methods used to formulate a strategy. Two factors, strength and weakness, are related to internal factors, while opportunity and threat are external factors (Oreksi, 2012). David (2004) and Rangkuti (2006) explained that the analytical tools used in formulating a strategy are IFE matrix, EFE matrix, IE matrix, SWOT matrix, and grand strategy matrix (SWOT Diagram Matrix). 


\section{RESULT AND DISCUSSION}

\section{Development strategy of coffee in Jambi Province}

Strength, weakness, opportunity, and threat are identified based on the results of the analysis of internal environment and external environment.

\section{Strength}

\section{a. Good Quality Coffee}

Coffee planted in Jambi Province is a good quality coffee. They are cultivated in some region with each has different type of coffee. Arabica beans have been a mainstay in Kerinci Regency, Robusta beans are founded in Merangin Regency, while Liberika coffee beans only grow in peat soil such in West Tanjung Jabung Regency.

From the survey, it was found that $78 \%$ of farmers use superior seeds, $12 \%$ of them use seeds from the existing parent trees on the land, and 10 percent of them use seeds from old coffee. As many as 77 percent of farmers using superior seeds received the seeds from government assistance through Estate Crops Office and 23 percent buy the seeds from seeds sellers in their village. Large proportion of coffee farmers using superior seeds is also founded in the study of Evizal (2013) in West Lampung. In addition, it was found that there is a usage of coffee seeds from ripe fruit of local superior coffee trees.

According to Nurhakim, Rahayu, and Nurmalasari (2014), choosing the good quality seeds also determines the success of coffee plantation businesses. It is in line with the statement of Hasnam (2007) which said that superior seeds have an important role in productivity, good quality products, and production efficiency. Lisyati (2013) in Lampung found different result, and concluded that owning small land likely to make farmers reluctant to use superior seeds.

\section{b. Coffee plantations area can be expanded}

Related to the availability of land, coffee plantations owned by farmers in Jambi Province are possible to be expanded by opening new land for coffee plantation or replacing old plants that are no longer productive. Findings indicate that there is conversion of lands for cinnamon, coconut, and vegetables into coffee plantation.

The average area of Robusta plantations owned by farmers in Merangin Regency is 1.2 hectares, of Arabica plantations in Kerinci Regency is 1.65 hectares and of Libtukom plantations in West Tanjung Jabung Regency is 1.33 hectares. These figures are relatively larger when it is compared to the finding of Listyati, Sudjarmoko \& Hasibuan (2013) in Lampung and of Maridelana, Hariyati \& Kuntadi (2014) in Bangli Regency, in which the average area owned by farmers is below 1 hectare.

\section{c. Coffee production continues to increase}

Coffee production in Jambi Province continues to increase every year. In 2016, Jambi Province's coffee production was 13,181 ton and it experienced an increase of 6.835 percent for year 2017. It was possible because there was an increase in the land area of productive plants from 15,684 hectares (2016) to 16,036 hectares (2017), experiencing an increase of 1.084 percent (Estate Crops Office, Jambi Province 2019).

From the survey conducted, it is found that the average production of Robusta is $800-1400 \mathrm{~kg}$ per harvest, Arabica production is $550-680 \mathrm{~kg}$ per harvest, and libtukom production is $500 \mathrm{~kg}$ per harvest. It can experience a significant increase in the peak harvest. Farmers harvested coffee beans every day which is then collected for a week or a month, with an average production of $5 \mathrm{~kg} /$ day. Ninety seven percent of them stated that they continued to cultivate, while the rest (three percent) of them said they did not 
continue due to obstacles in the form of coffee diseases that suddenly attack shoots.

Productivity for Arabica beans in Jambi is relatively higher than the productivity in Solok Regency, found by Putri, Yusmarni, Paloma \& Zakir (2018)'s research, which is $570.5 \mathrm{~kg}$ per hectare. For Robusta, its productivity is also higher if it is compared to the finding of Kiyingi \& Gwali (2012) in Uganda which has an average of $748 \mathrm{~kg}$ per hectares for fertilized coffee and $486 \mathrm{~kg}$ per hectare for coffee without fertilizer.

\section{d. Owning Geographical Indication (GI) certificate}

GI certificate is a sign indicating the area of origin of products and/or goods based on the geographical factors which give certain characteristics and qualities to the goods/products. GI certificate is coffee patent. This certificate can protect Indonesian products in global market (Rahmatullah, 2014).

GI certificate guarantees and maintain the quality and authenticity of coffee. Arabica coffee from Kerinci and Libtokum coffee from West Tanjung Jabung have GI certificate. All farmers in Kerinci Regency and West Tanjung Jabung regency are aware of GI certificate for the coffee they produce. The farmers from these two regions have joined the Community Protection of Geographical Indications or Masyarakat Perlindungan Indikasi Geografis (MPIG). On the contrary, no farmers in Merangin Regency have known about IG certificate.

e. Distinctive characteristics of coffee, different from other region's coffee

Coffee produced in Jambi Province has a different taste from other coffees in Indonesia. This distinctive taste made Arabica coffee from Kerinci became the best Indonesian specialty coffee in 2017. Robusta from Merangin won the best Indonesian Robusta award in the Expo of Specialty Coffee Association of Indonesia (SCAI).

\section{f. Own Capital}

Almost all (95 percent) farmers use their own capital, and only five percent of them get loans from their relatives, through leasing, and banking.

\section{Weakness}

Although Jambi Province's coffee has several strengths, it also has some weaknesses:

\section{a. Coffee selling price is not determined by farmers}

Farmers sell dried coffee beans at a determined price by their buyer. This finding is in line with the finding of Tanan, Limbongan \& Tangkesalu (2013) concluding that farmers as coffee producers still sell their products at the price set unilaterally by coffee trades.

Selling price of Libtukom coffee at the farmer level is Rp. 25,500 per kilogram which is the highest when it is compared to Robusta coffee's price of Rp. 18,000/kg and Arabica coffee of Rp. 10,000/kg. Unlike Robusta and Libtukom, Arabica is sold in the form of freshly harvested coffee cherries so it has a low price.

The average selling price of Libtukom coffee at the seller/trader level is Rp. 40,000 per kilogram, Robusta coffee is Rp. 22,000 per kilogram and Arabica coffee is Rp. 19,500 per kilogram. Cheap prices from farmers are due to lack of market information and inability of farmers to meet the required standard of product quality by large traders, exporters, processed coffee entrepreneurs, and end users.

\section{b. Coffee sales are through brokers/middleman}

Farmers prefer to sell their products to brokers/middleman. Most (81 percent) of them sell coffee to brokers/middleman and only 19 percent of them sell coffee directly to large traders/sellers. 


\section{c. Few types of products}

Products from coffee farmers in Jambi Province are still very limited. Most (86 percent) of farmers sell coffee beans and only 14 percent of them have done further processing such as ground coffee. The processing is not only done by farmers but also by SMEs and Cooperatives.

\section{d. Lack of promotion and lack of wide distribution network}

Promotion of coffee products is still relatively limited. In general, it is only carried out by local governments through national and international exhibitions.

\section{e. Limited science and technology innovations}

Innovations by coffee farmers are still limited. The production process still uses traditional method in general, both in terms of the dry process (only relying on sunlight) and stripping.

\section{Opportunity}

There are many opportunities to develop Jambi Province's coffee commodities, such as:

\section{a. Export market is largely available}

Jambi Province's coffee is much in demand by foreign coffee lovers because it has the distinctive characteristic that is different from coffee from other regions. Opportunities for coffee exports to Malaysia and Singapore are still largely available for Liberika coffee, while Arabica coffee is in high demand in European countries (m.wartaekonomi.co.id).

\section{b. Lower level of coffee product diversification}

Product diversification from coffee beans can have an impact on increasing the income of coffee farmers. From the survey results, it is found that the price of coffee beans is Rp. 20,000 per kilogram, while the price of ground coffee is an average of 25,000 per 200 grams, for Robusta, Arabica, and Libutkom.

\section{c. The existence of MSMEs processing coffee beans on a small scale}

There are a number of MSMEs that process coffee beans in Jambi Province. Three MSMEs are in Merangin, processing Robusta coffee. In Kerinci, there are eleven MSMEs processing Arabica coffee, while four MSMEs processing Libtukom coffee are in West Tanjung Jabung. It should be noted, however, the downstream coffee industry is still in a small scale. Based on the research findings of Nalurita, Winandi \& Jahroh (2014) and Fadhil, Qanytah, Hastati \& Maarif (2018), these small-scale industries have limited production facilities and infrastructures, lacks innovation in diversify coffee products, lower quality of coffee production, and bad management.

\section{d. Marketing through online media}

With current technological advancements, marketing is not a major issue. Marketing through online media is one of the best ways of marketing to this day and it does not require a large budget. However, the use of online media at present in coffee marketing remains limited. The survey results show that online marketing is only carried out by MSMEs in West Tanjung Jabung and Kerinci, through Facebook and Instagram.

\section{Threat}

Threats in the development of coffee commodities in Jambi Province include:

\section{a. Coffee from other regions has lower price}

Although Robusta, Arabica, and Libtukom coffees are the mainstay of Jambi 
Province, the price which is more expensive than that of other regions' coffee is important issues that must be get government's attention. Jambi Province's ground coffee price in 200 grams packaging is Rp. 25,000 while the price of coffee from other regions is Rp. 10,000 per 250 grams.

\section{b. Diseases attacking coffee trees}

Diseases attacking coffee trees are significant threats to coffee production. It does not only attack coffee trees that had yet produced, but also productive coffee plants. One of the diseases is that the coffee plants suddenly die.

Around 1.73 percent of Robusta coffee plantations in Merangin Regency and 0.87 percent of Libtukom coffee plantations in West Tanjung Jabung are experiencing such diseases.

\section{c. Unstable coffee prices}

Unstable coffee price is a threat to the sustainability of coffee plantations in Jambi Province. Price fluctuation of coffee beans is a major problem for coffee farmers, so that coffee is not a main livelihood of the community in Jambi Province. The selling price of coffee beans or the income gained by farmers varies with each harvest. The lowest price for Robusta coffee is Rp. 7,000/kg, for Arabica coffee is Rp. 10,000/kg and Libtukom coffee is Rp. 14,000/kg. The highest price for Robusta is Rp. 21,000/kg, Arabica's is Rp. $20,000 / \mathrm{kg}$, and Libtukom's is Rp. 38,000/kg.

\section{Formulation of alternative strategies for development of coffee}

Strategy formulation is carried out through three stages, namely input stage (IFE matrix and EFE matrix), matching stage (IE matrix and SWOT matrix), and decisionmaking stage (QSPM matrix).

\section{IFE matrix}

Based on the results of identification of internal factors, namely strength and weakness, the calculation of the IFE matrix is presented in Table 2.

Table 2. IFE matrix, model and strategies for development of coffee commodity in Jambi Province

\begin{tabular}{lccc}
\hline Internal strategic factors & Weight & Rating & $\begin{array}{r}\text { Weighted } \\
\text { score }\end{array}$ \\
\hline Strengths & & & \\
\hline 1. Good quality coffee & 0.073 & 4.000 & 0.291 \\
2. Coffee plantations area can be expanded & 0.099 & 3.500 & 0.346 \\
3. Coffee production continues to increase & 0.073 & 4.000 & 0.291 \\
4. Owning Geographical Indication (GI) certificate & 0.116 & 3.750 & 0.435 \\
5. Distinctive characteristics of coffee, different from other & & & \\
$\quad$ region's coffee & 0.107 & 4.000 & 0.427 \\
6. Own capital & 0.092 & 3.750 & 0.345 \\
\hline Weaknesses & & & \\
\hline 1. Coffee selling price is not determined by farmers & 0.063 & 1.500 & 0.094 \\
2. Coffee sales are through brokers/middleman & 0.074 & 1.250 & 0.092 \\
3. Few types of products & 0.108 & 1.500 & 0.162 \\
4. Lack of promotion and lack of wide distribution network & 0.092 & 2.000 & 0.184 \\
5. Limited science and technology innovations & 0.103 & 1.500 & 0.155 \\
\hline Total & 1.000 & & 2.822 \\
\hline
\end{tabular}

Based on the IFE matrix, it can be seen that the strength factor that has the highest score is GI certificate of 0.435 . Geographical Indication is an important strength in the development of coffee commodities. Silitonga's (2008) research findings show that one 
of the competitive advantages of organic Gayo Arabica coffee is that it has Gayo as its geographical indications.

Main weakness in the development of coffee commodities in Jambi Province $i$ s the coffee trade system through brokers/middleman with a score of 0.092 . The absence of alternative ways to sell coffee beans causes farmers to sell it to brokers/middleman. Another weakness is the selling price of coffee that is not determined by farmers with a score of 0.094 .

Overall, the total weighted score of strengths and weaknesses in the IFE matrix is 2.822 which is above the average score of 2.50 . Based on this, it can be concluded that the development of coffee commodities in Jambi Province is in a strong position in taking advantages of its strengths and is quite capable to overcome weaknesses.

\section{EFE matrix}

Opportunities and threats can be seen from the availability of quite large lands, human resources as labor, the presence of local markets, regional markets in the province and outside the province, and international markets, the existence of local government support and the availability of connecting facilities and other supporting institutions (Rika, Febriamansyah \& Tanjung, 2016).

The EFE matrix is used to find out the influence of external factors. It is carried out based on the identification of external environment in the form of opportunities and threats.

Table 3. EFE matrix, model and strategies for development of coffee in Jambi Province

\begin{tabular}{lccc}
\hline External strategic factors & Weight & Rating & Weighted score \\
\hline Opportunities & & & \\
\hline 1. Export market is largely available & 0,167 & 3,500 & 0,583 \\
2. Lower level of coffee product diversification & 0,176 & 2,250 & 0,395 \\
3. The existence of MSMEs processing coffee beans & & & \\
$\quad$ on a small scale & 0,152 & 3,750 & 0,569 \\
4. Marketing through online media & 0,164 & 2,000 & 0,327 \\
\hline Threat & & \\
\hline 1. Coffee from other regions has lower price & 0,134 & 1,500 & 0,201 \\
2. Diseases attacking coffee trees & 0,092 & 3,250 & 0,300 \\
3. Unstable coffee prices & 0,116 & 3,500 & 0,406 \\
\hline Total & 1.000 & & 2.782 \\
\hline
\end{tabular}

Based on Table 2., the biggest opportunity is export market share is largely available with the score of 0.583 . It indicates that the coffee commodity of Jambi Province has the opportunity to be an export commodity. The existence of MSMEs processing coffee beans on a small scale has a score of 0.569 .

The main threat faced in developing coffee in Jambi Province is coffee from other regions has a lower price with the score of 0.201 . Diseases attacking coffee trees are also threats that must be given attention. Diseases causing coffee trees to die suddenly make coffee farmers to become confused and discourage, so their coffee production and enthusiasm decline.

Overall, total weighted score from four opportunities and three threats on the EFE matrix is 2.782 or above the average score of 2.50 . It can be concluded that the development of coffee in Jambi Province is able to respond to the external environment by taking opportunities to face threats.

\section{IE matrix}

The IE matrix is based on the analysis of internal and external factors, combined from IFE matrix and EFE matrix. IE matrix can be seen in Figure 3. 


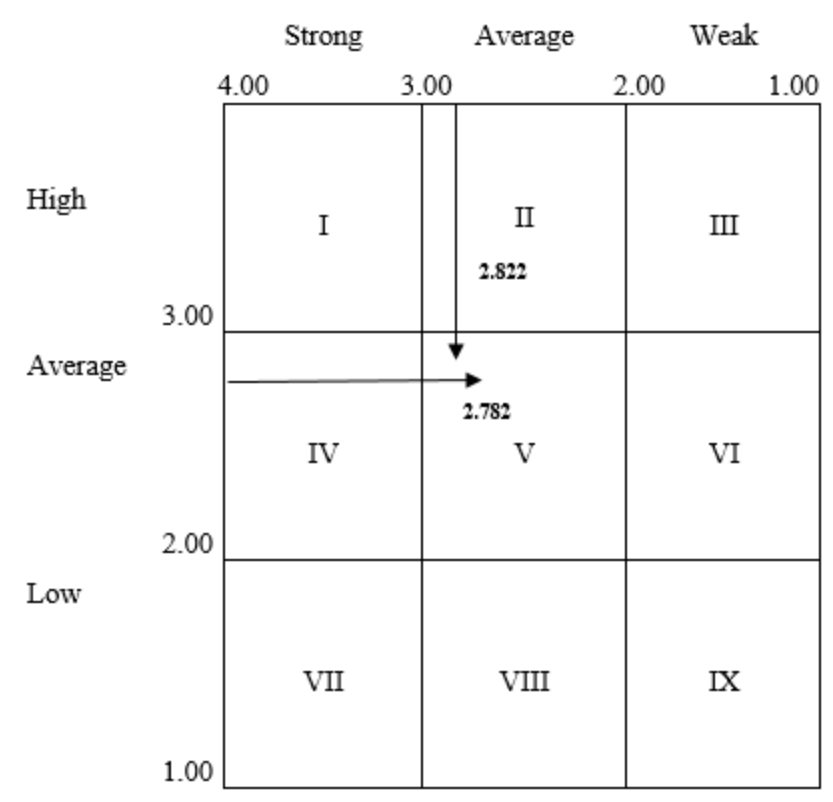

Figure 1. IE matrix for development of coffee in Jambi Provinces

The total weighted score from IFE (2.822) matrix and EFE matrix (2.782) place the development of coffee commodities in Jambi Province in cell V in IE matrix. Strategy than can be taken based on the position of cell is hold and maintain strategy. The best strategy that can be taken is market penetration strategy and product development strategy.

\section{SWOT matrix}

Integration of internal and external factors in the SWOT matrix generates several strategic alternatives that can be used in the development of coffee commodities in Jambi Province. It generates four sets of possible strategic alternatives namely S-O strategy, ST strategy, W-O strategy, and W-T strategy. These strategies can be seen in Table 4.

Table 4. SWOT matrix, model and strategies for development of coffee in Jambi Province

\begin{tabular}{|c|c|c|}
\hline External factors & $\begin{array}{l}\text { Strengths : }(\mathbf{S}) \\
\text { 1. Good quality coffee } \\
\text { 2. Coffee plantations area can be } \\
\text { expanded } \\
\text { 3. Coffee production continues to } \\
\text { increase } \\
\text { 4. Owning GI certificate } \\
\text { 5. Distinctive characteristics of } \\
\text { coffee, different from other } \\
\text { region's coffee } \\
\text { 6. Own capital }\end{array}$ & $\begin{array}{l}\text { Weaknesses : }(\mathbf{W}) \\
\text { 1. Coffee selling price is not } \\
\text { determined by farmers } \\
\text { 2. Coffee sales are through } \\
\text { brokers/middleman } \\
\text { 3. Few types of products } \\
\text { 4. Lack of promotion and lack of } \\
\text { wide distribution network } \\
\text { 5. Limited science and } \\
\text { technology innovations }\end{array}$ \\
\hline $\begin{array}{l}\text { Opportunities : }(\mathbf{O}) \\
\text { 1. Export market is largely } \\
\text { available } \\
\text { 2. Lower level of coffee } \\
\text { product diversification } \\
\text { 3. The existence of MSMEs } \\
\text { processing coffee beans } \\
\text { Online marketing }\end{array}$ & $\begin{array}{l}\text { S-O strategy } \\
\text { 1. Cooperation development with } \\
\text { export destinations } \\
\text { 2. Coffee products innovations } \\
\text { (S3, S4, S5 and O1, O2) }\end{array}$ & $\begin{array}{l}\text { W-O strategy } \\
\text { 1. Cutting off distribution } \\
\text { channels } \\
\text { 2. Direct cooperation with related } \\
\text { agencies (W1, W2 and O1) }\end{array}$ \\
\hline $\begin{array}{l}\text { Threats : }(\mathbf{T}) \\
\text { 1. Coffee from other regions } \\
\text { has lower price } \\
\text { 2. Diseases attacking coffee } \\
\text { trees } \\
\text { 3. Unstable coffee prices }\end{array}$ & \begin{tabular}{l}
\multicolumn{1}{c}{ S-T strategy } \\
1. Increase promotion of Jambi \\
Province's coffee \\
2. Making Jambi's coffee as one \\
of the icons of Jambi Province \\
(S3, S4, S5 and T1)
\end{tabular} & $\begin{array}{l}\quad \text { W-T strategy } \\
\text { 1. Improving knowledge and } \\
\text { coffee processing } \\
\text { technology } \\
\text { 2. Improving human resources } \\
\text { (W3, W5 and T1) }\end{array}$ \\
\hline
\end{tabular}




\section{QSPM Matrix}

Selection of priority strategic alternatives to be implemented is carried out using the QSPM matrix, given in Table 5.

Table 5. QSPM matrix, strategic alternatives for the development of coffee commodities in Jambi Province to respond the global market demand

\begin{tabular}{lccc}
\hline Strategies & Linkage & TAS & Rank. \\
\hline 1. Cooperation development with export destinations & S3, S4, S5 and O1 & 5.340 & V \\
2. Coffee products innovations & S3, S5 and O2 & 5.458 & IV \\
3. Cutting off distribution channels & W1, W2 and O1 & 5.636 & I \\
4. Direct cooperation with related agencies & W5 and O3 & 5.124 & VI \\
5. Increase promotion of Jambi Province's coffee & S4, S5 and T1 & 5.584 & III \\
$\begin{array}{l}\text { 6. Making Jambi's coffee as one of the icons of } \\
\text { Jambi Province }\end{array}$ & S4, S5 and T1 & 5.598 & II \\
$\begin{array}{l}\text { 7. Improving knowledge and coffee processing } \\
\text { technology }\end{array}$ & W3, W5 and T1 & 5.025 & VII \\
8. Improving human resources & W1, W2 and T2 & 4.878 & VIII \\
\hline
\end{tabular}

Based on the results of the QSPM matrix analysis, the most appropriate priority of strategies are:

1. Cutting off the distribution channel is the main strategy with a TAS value of 6.636 . This measure has an impact on increasing the selling price of coffee which has not benefited farmers in coffee sales. May \& Mascarenhas (2004) argues that there are many challenges in the coffee trade, but there are several opportunities, including maintaining long-term cooperation agreements between producers and consumers.

2. Making Jambi's coffee as one of the regional icons has the highest TAS value of 5.598. In addition to Jambi batik, three types of coffee from Jambi Province namely Arabica, Robusta, and Libtukom can be promoted as icons of Jambi Province.

3. Increasing the promotion of Jambi Province's coffee has a TAS value of 5.584. One of the ways to promote is giving Jambi's coffee as a gift or souvenir for tourists. Another one is holding exhibitions both in national and international events.

4. Development of coffee product innovation has a TAS value of 5.458. Innovation must continue to be present in order to provide more added-values to the coffee. Related to this strategy, Sitanggang (2013) stated that establishing a coffee research and development institute creates new innovations in improving the quality and quantity of coffee.

5. Development of cooperation with export destinations has a TAS value of 5.340. By implementing this strategy, the marketing of Jambi Province's coffee has no longer have difficulties to meet global market demand because there will a large coffee production.

6. Cooperating/Working directly with related agencies has a TAS value of 5.124. One way to cut distribution channels is to establish cooperatives or storages for coffee beans produced by farmers. Related agencies such as Estate Crops Office and Trade and Industry Service could collect farmer's coffee beans and sell them directly to consumers.

7. Improving knowledge and coffee processing technology has a TAS value of 5.025. Training to increase knowledge and use of technology has a positive impact on production to be more efficient and effective so the cost of processing can be reduced.

8. Improving human resources has a TAS value of 4.878. It will have an impact on increasing the development of coffee in Jambi Province. 


\section{Jambi Province's coffee development model}

Development of Jambi Province's coffee began by cutting off the distribution channels for coffee sales. Farmers will sell coffee to cooperatives which then work together with Estate Crops Office and Trade and Industry Service to distribute coffee products directly to destination countries, and also to promote coffee.

Local government will provide counseling and improvement of knowledge and technology to coffee farmers through trainings, workshops, good-quality coffee seeds and creating innovative products that can be accepted in the market. From the several priority strategies in developing Jambi Province's coffee, a model can be generated as shown in the figure below.

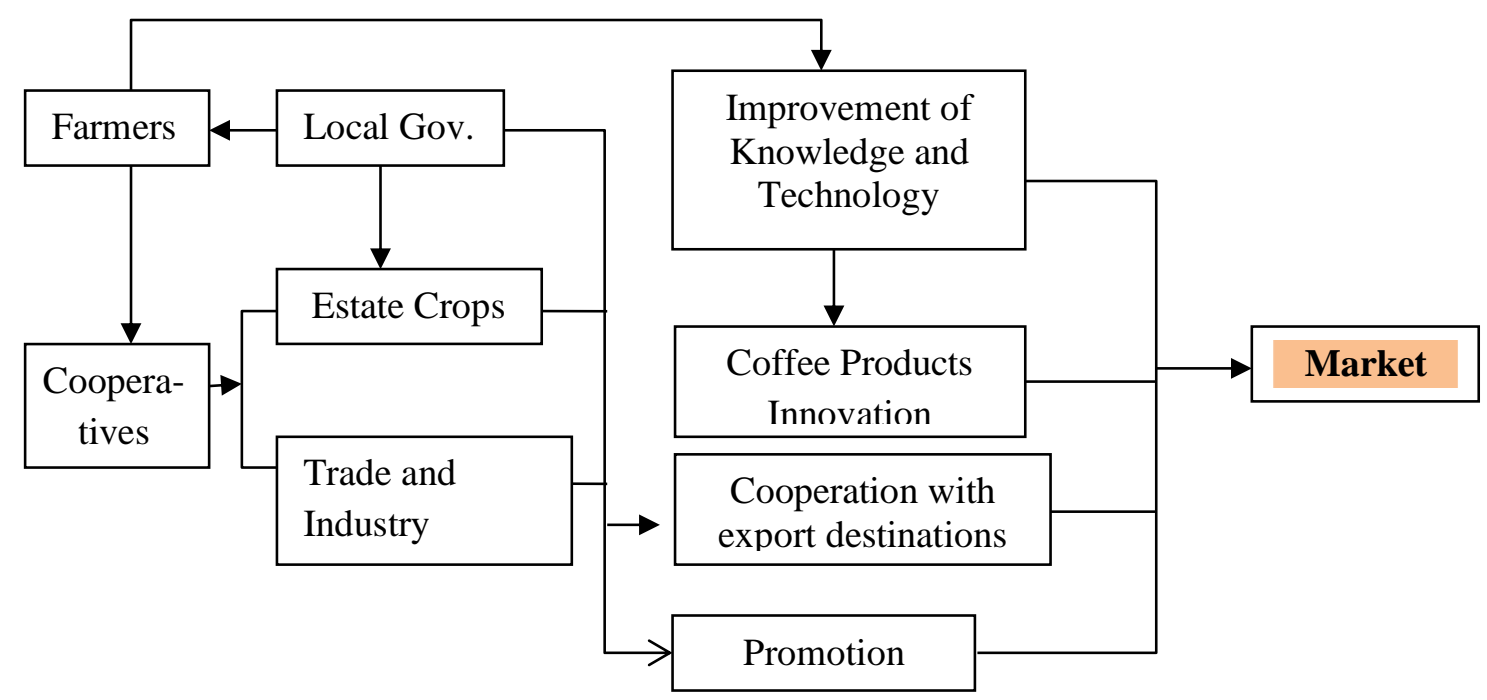

Figure 2. Jambi Province's coffee development model

Coffee agribusiness development is a synchronization of four agribusiness subsystems, namely upstream sub-agribusiness, primary sub-agribusiness, downstream sub-agribusiness, and supporting sub-agribusiness (Bilhak \& Ma'arif, 2014).

\section{CONCLUSION AND RECOMMENDATIONS}

\section{Conclusion}

There are eight strategies for developing Jambi Province's coffee. Those strategies are cutting off distribution channels, working directly with relevant agencies, increasing promotion of coffee as one of the Jambi Province icons, cooperation with export destinations, coffee product innovations, improving knowledge and processing technology of coffee, and improving human resources. From the existing strategy, a good development model is to involve all components starting from coffee farmers, local government, and cooperation with export destinations that can ultimately meet global market demand.

\section{Recommendations}

Government and farmers must work together especially in cutting off the distribution channel of coffee which is detrimental to farmers. They also must work in carrying out training and coaching for the existing MSMEs which has to be the focus of all parties to further make innovations for coffee products. Existing cooperation with several countries has to be maintained well so that coffee exports to those countries will go well in a long period. 


\section{REFERENCES}

AEKI. (2017). Ekspor Kopi. http://www.aeki-aice.org/coffee_export_regulations.html. Date accessed: 22 February 2019

Badan Pusat Statistik, (2018). Statistik Kopi Indonesia. Jakarta: BPS

Bilhak, A. \& Ma'arif, S. (2014). Pengembangan Agribisnis Kopi Dalam Kerangka Pembangunan Ekonomi Wilayah di Kabupaten Aceh Tengah (Studi Kasus Kabupaten Aceh Tengah). Jurnal Teknik PWK, 3(2), 254 - 261.

David, F.R. (2006). Manajemen Strategi : Konsep. Jakarta: Salemba Empat

Dinas Perkebunan, (2019). Statistik Perkebunan Provinsi Jambi. Jambi: Dinas Perkebunan

Evizal, R. (2013). Etno-agronomi Pengolahan Perkebunan Kopi di Sumberjaya Kabupaten Lampung Barat. Jurnal Agrotrop, 3(2), 1 - 12

Fadhil, R., Qanytah, Q., Hastati, D.Y. \& Maarif, M. (2018). Development Strategy for a Quality Management System of Gayo Coffee Agro-Industry Using Soft Systems Methodology. Periodica Polytechnica Social and Management Sciences, 26(2), 168178. https://doi.org/10.3311/PPso.11341.

Hasnam. (2007). Status Perbaikan dan penyediaan bahan tanaman jarak pagar (Jatropha curcas L). Proceedings of Lokakarya II Status Teknologi Tanaman Jarak Pagar. (pp. 7-16). Bogor: Pusat Penelitian dan Pengembangan Perkebunan.

International Coffee Organization. (2017). World Coffee Market Outlook. http://.ico.org. Date accessed: 23 February 2019.

Indonesia Investment. (2018). Produksi domestik, ekspor dan konsumsi kopi indonesia. https://www.indonesia-investments.com/id/bisnis/komoditas/kopi/item186?. Date accessed: 16 February 2019.

Kiyingi, I \& Gwali, S. (2012). Productivity and Profitability of Robusta Coffee Agroforestry System in Central Uganda. Uganda Journal of Agricultural Sciences, 13(1), $85-93$

Kustiari, R. (2007). Perkembangan Pasar Kopi Dunia dan Implikasinya bagi Indonesia. Forum penelitian Agroekonomi, 25(1), 43-55. http://dx.doi.org/10.21082/ fae.v25n1.2007.43-55

Listyati, D., Sudjarmoko, B. \& Hasibuan, A.M. (2013). Analisis Faktor - Faktor Yang Mempengaruhi Adopsi Benih Unggul Kopi di Lampung. Jurnal Tanaman Industri dan Penyegar, 4(2), 165 - 174.

May, H.P \& Mascarenhas, G.C.C Potts, J. (2004). Sustainable Coffee Trade The Role of Coffee Contracts. Paper by the International Institute for Sustainable Development https://www.iisd.org/pdf/2004/sci_coffee_contracts.pdf. Date accessed: 23 July 2019.

Maridelana, V.P., Hariyati, Y. \& Kuntadi, E.B. (2014). Fungsi Keuntungan Usahatani Kopi Rakyat di desa Belantih Kecamatan Kintamani Kabupaten Bangli. Berkala Ilmiah Pertanian, 1(3), 47-52

Martauli, E.D. (2018). Analisis Produksi Kopi di Indonesia. Journal Of Agribusiness Sciences, 1(2), 112-120

Nalurita, S., Winandi, R. \& Jahroh, S. (2014). Analisis Daya Saing dan Strategi Pengembangan Agribisnis Kopi di Indonesia. Jurnal Agribisnis Indonesia, 2(1), 63 - 74. https://doi.org/10.29244/jai.2014.2.1.63-74

Nurhakim, Y.I, Rahayu \& Nurmalasari. (2014). Perkebunan Kopi Skala Kecil Cepat Panen. Jakarta: Infra Pustaka.

Oreksi, D. (2012). Strategy Development by using SWOT-AHP. TEM Journal, 1(4), $283-291$ 
Putri, A., Yusmarni, Paloma, C. \& Zakir, Z. (2018). Kinerja Faktor Produksi Kopi Arabika di Lembah Gumanti, Kabupaten Solok, Sumatera Barat. Industria: Jurnal Teknologi dan Manajemen Agroindustri, 7(3), 189-197. http://dx.doi.org/10.21776/ ub.industria.2018.007.03.7

Rangkuti, F. (2006). Analisis SWOT: Teknik membedah kasus bisnis. Jakarta: Gramedia Pustaka Utama.

Rahmatullah, I. (2014). Perlindungan Indikasi Geografis Dalam Hak Kekayaan Intelektual Melalui Ratifikasi Perjanjian Lisabon. Jurnal Citra Hukum, II(2), 305316. http://dx.doi.org/10.15408/jch.v1i2.1470

Rika, H., Febriamansyah, R. \& Tanjung, F. (2016). Strategi pengembangan agribisnis kopi robusta di Kabupaten Solok. Jurnal Agrisep, 15(1), 111 - 126

Silitonga, CM. (2008). Analisis keunggulan bersaing kopi arabika gayo organik di Indonesia (Master Thesis). Retrieved from http://repository.ut.ac.id/1781/

Sitanggang, J.T.N (2013). Pengembangan potensi kopi sebagai komoditas unggulan kawasan agropolitan di Kabupaten Dairi. Jurnal Ekonomi dan Keuangan, 1(6), 33 48

Sudjarmoko. B. (2013). Peluang dan Tantangan Pasar Kopi Indonesia di Pasar Domestik dan Pasar Internasional. Media Komunikasi Tanaman Industri dan Penyegar, 1(2), $99-110$.

Tanan A., Limbongan, Y.L. \& Tangkesalu, J. (2013). Studi Rantai Tata Niaga Kopi Toraja. AgroSainT, IV(1), 435-438. 